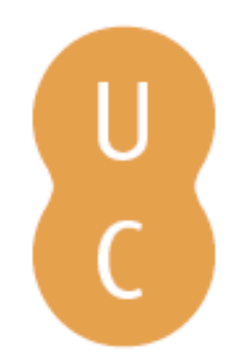

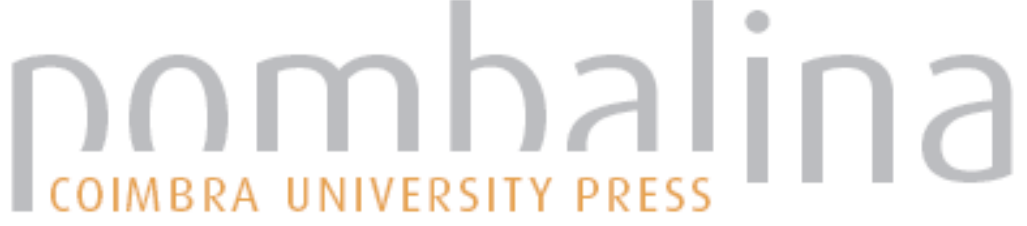

The Darwinian revolution in the sciences of life and man

Autor(es): $\quad$ Pereira, Ana Leonor

Publicado por: Imprensa da Universidade de Coimbra

URL

persistente: URI:http://hdl.handle.net/10316.2/31255

DOI: $\quad$ DOI:http://dx.doi.org/10.14195/978-989-26-0342-1_1

Accessed : $\quad$ 26-Apr-2023 11:16:49

A navegação consulta e descarregamento dos títulos inseridos nas Bibliotecas Digitais UC Digitalis, UC Pombalina e UC Impactum, pressupõem a aceitação plena e sem reservas dos Termos e Condições de Uso destas Bibliotecas Digitais, disponíveis em https://digitalis.uc.pt/pt-pt/termos.

Conforme exposto nos referidos Termos e Condições de Uso, o descarregamento de títulos de acesso restrito requer uma licença válida de autorização devendo o utilizador aceder ao(s) documento(s) a partir de um endereço de IP da instituição detentora da supramencionada licença.

Ao utilizador é apenas permitido o descarregamento para uso pessoal, pelo que o emprego do(s) título(s) descarregado(s) para outro fim, designadamente comercial, carece de autorização do respetivo autor ou editor da obra.

Na medida em que todas as obras da UC Digitalis se encontram protegidas pelo Código do Direito de Autor e Direitos Conexos e demais legislação aplicável, toda a cópia, parcial ou total, deste documento, nos casos em que é legalmente admitida, deverá conter ou fazer-se acompanhar por este aviso.

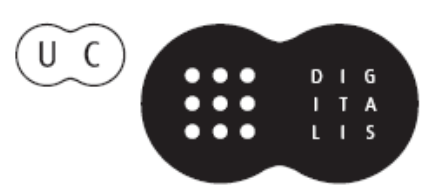


Ana Leonar Pereira João Rui Pita

Pedro Ricarda Fonseca (eds.)
Darwin,

Evalution,

Evolutionisms

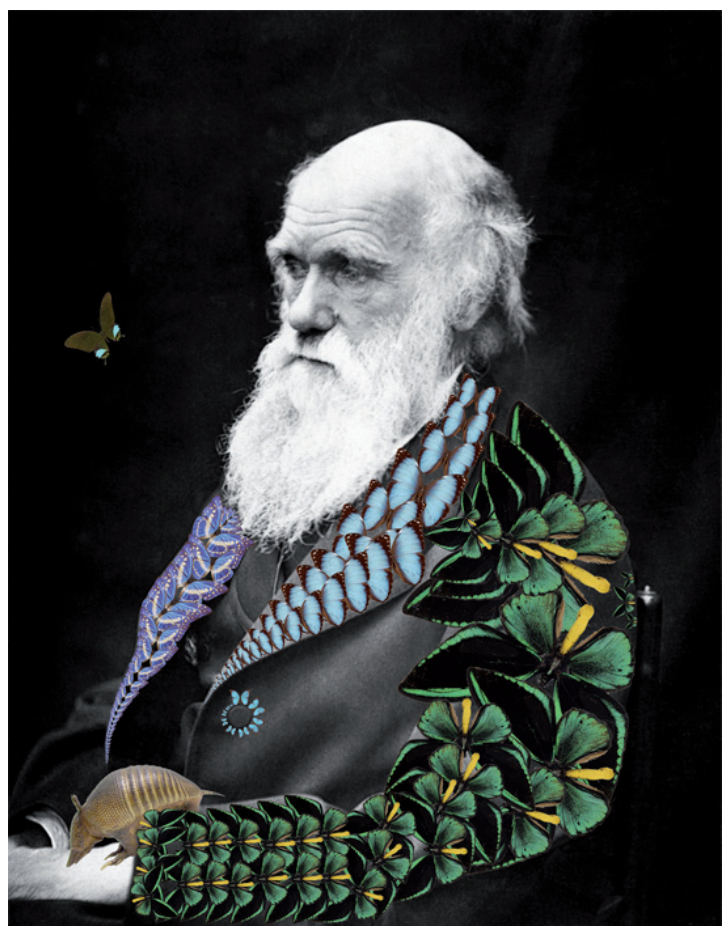


Ana Leonor Pereira

Faculdade de Letras; CEIS20-Grupo de História e Sociologia da Ciência,

Universidade de Coimbra, Portugal

\section{The Darwinian revolution in the sciences of Life and Man ${ }^{1}$}

In 1859, with the publication of $O n$ the origin of species by means of natural selection, or the preservation of favoured races in the struggle for life, Darwin inaugurated a new understanding of the historicity and the diversity of living organisms, including the human species. This new understanding is called descent with modification by natural selection. According to Darwinian theory, plant and animal species, including the human species, reproduce at such a fast rate and so abundantly that the struggle for life becomes inevitable: the struggle among individuals of the same species, the struggle among individuals of different species, the struggle with the physical conditions of life; the struggle for food, the struggle for descent, the struggle for territory. Species multiplication is the force that initiates the struggle from which the survival of the fittest and the elimination of the least fit will take place, i. e., the natural selection of the advantageous variations and, consequently, adaptive evolution. Although the struggle is fundamental, not-less important is the raw material upon which natural selection operates: variation. Natural selection is more than a mechanism solely devoted to the preservation and elimination of (respectively) favourable and harmful individual variations in the adaptation process; it is also a "creative" agency, albeit without any sort of a priori project - a feature well illustrated by Charles Darwins' diagram of the tree of life.

Alluding to François Jacob's book The Possible and the Actual - that is urging a new Portuguese edition -, we will state that variations are integrated and disposed "in adaptive coherent sets, adjusted during millions and millions of generations, in response to the challenge of the environment. It is natural selection that [...] slowly, progressively, elaborates more complex structures, new organs, new species". ${ }^{2}$ In the "bricolage of evolution" (Jacob: 57-97; our italics), the randomness of variations and the constant interaction of organisms with the environment, intersected by contingency, structures the history of life. Thus, the theory of descent with modification by natural selection also distances itself from vitalistic theologisms, whether from previous transformist theories, whether from the traditional essentialist fixism. According to François Jacob, "the Darwinian conception has, therefore, a fatal consequence: the present living

\footnotetext{
${ }^{1}$ The contents of the present chapter have been addressed in greater detail in: PEREIRA, Ana Leonor, Darwin em Portugal, Coimbra, Almedina, 2001.

2 Translated into English from the Portuguese edition: JACOB, François. 1985. O jogo dos possiveis. Ensaio sobre a diversidade do mundo vivo. Lisboa: Gradiva, p. 34.
} 
world, as we perceive it, is only one amongst many other possible. (...) It could well have been different. It could even not exist at all" (Idem: 34-35).

Darwin verifies the struggle of living beings among themselves, for territory, for food, for descent, being the survival of the fittest (natural selection), i. e., the survival of those that present useful and advantageous variations, the keystone of the genealogical differentiation by divergence and isolation. According to the Darwinian paradigm, the living world does not bear the marks of necessity and of perfecting harmony, neither is it the only, or the best, of all possible worlds, as postulated by Lamarck's transformism. It bears the marks of randomness, of contingency, of unpredictability, of imperfection and improvisation. Half a century after Lamarck's Philosophie Zoologique (1809), the Darwinian paradigm revolutionised both essentialist creationism and Lamarckian transformism.

Darwin's scientific revolution was possible thanks to a set of factors of diverse nature, among which, undoubtedly, we have to highlight the progresses achieved in the Earth and Life sciences, during the first half of the $19^{\text {th }}$ century. It is the case of Charles Lyell's Principles of Geology (1830-1833), and his doctrine of actual causes or actualism/ uniformitarianism. A good deal of knowledge on geology, biogeography, palaeontology, embryology and other fields, the voyage of the Beagle, Malthus' Principle of Population, the anxiety caused by the essay of the naturalist A. R. Wallace in 1858, the genius of Darwin - these are some of the factors usually invoked to explain the Darwinian revolution in the sciences of Life and Man. Like the scientific revolutions led by Newton in 1687, by Planck in 1900, by Einstein in 1905, Darwin also spent around twenty years (1839-1859) to elaborate and turn public the theory of descent with modification by natural selection. Darwin was thirty years old when he started to conceive the new theory and at the age of fifty he published his masterpiece The Origin of Species which spread all over the world, in eleven languages until his death in 1882, and in a total of twenty-nine languages by 1977. Around twelve years later, Charles Darwin explored the "long argument" of 1859 in more detail, particularly regarding the human species, in The descent of man, and selection in relation to sex, 1871 and The expression of the emotions in man and animals, 1872. From our point of view, in these two books, Charles Darwin, although recognising and stating his lack of knowledge on the laws of heredity, continued his enormous endeavour of arguing in favour of the theory of descent with modification by natural selection, commonly known as the theory of evolution. It is important to recall that Charles Darwin, during the voyage of the Beagle (1831-1836), read Charles Lyell's Principles of Geology (1830-1833), and that the British geologist was publicizing Lamarckian transformism under the name of the theory of evolution. Due to this reason, and others, Darwin obviously avoided the term evolution.

It is in 1871 , in the first edition of the book The descent of man, that the noun evolution appears for the first time. Descent with modification becomes synonymous to gradual evolution. Later, in 1872, in the sixth edition of The Origin of Species, considered the definitive version, the term evolution appears five times. Evidently, the theory of gradual evolution, by natural selection of random variations, innovated the semantic charge of the term evolution, especially regarding the meaning that H. Spencer had generalised since 1852 in "The development hypothesis" (reproduced, for example, in Essays: scientific, political, and speculative. London, Williams and Norgate, 1868, vol. I, pp. 377-383). H. Spencer generalised the law of embryonic development (epigenesis) of Von Baer to build a universal philosophical formula: the evolutionary 
law of development from a simple, undifferentiated and incoherent homogeneity to a complex, differentiated and coherent heterogeneity.

In 1852, Spencer advanced the hypothesis of the evolution of species from the most simple monad (the homogeneity of a common egg, the only matrix of all living things), grounding his reflexion on embryologic development. The theory of evolution, "the Theory of Evolution" held by Herbert Spencer, since 1852, was much different from the theory of descent with modification published by Darwin in 1859. Darwin was perfectly aware that his The Origin of Species introduced a new evolutionary logic of life. This explains why, in the historical survey on the idea of the mutability of species before 1859 that Darwin included in the sixth edition of The Origin of Species, none of the thirty four authors mentioned are presented as pioneers of his evolutionary theory. Not even Lamarck or Herbert Spencer. Although Darwin's theory had given a new meaning to the term evolution, the misinterpretations were inevitable.

It has been acknowledged that Darwin linked natural selection to the Spencerian phrase "the survival of the fittest", and this linkage has functioned as a bridge to understand the lasting commitment between Darwinism and Spencerian Evolutionism in the history of international culture. Indeed, in the $5^{\text {th }}$ edition of The Origin of Species (1869), Darwin introduced the Spencerian expression "the survival of the fittest", not only in the text, but also in the title of chapter IV ("natural selection; or the survival of the fittest"). Darwin justified his usage of the Spencerian expression "the survival of the fittest" as synonymous of natural selection, saying textually: "the expression often used by Mr. Herbert Spencer of the Survival of the Fittest is more accurate, and is sometimes equally convenient". However, it was Herbert Spencer in his Principles of Biology (1864-1867), who took the initiative to identify the principle of "the survival of the fittest" with Darwinian natural selection: "\$ $\$ 165$. This survival of the fittest, which I have here sought to express in mechanical terms, is that which Mr. Darwin has called natural selection, or the preservation of favoured races in the struggle for life", (The principles of biology, London, Williams and Norgate, 1880, vol. 1, pp. 444-445). Darwin limited himself to accept the identification, proposed by Herbert Spencer, between the latter's expression "the survival of the fittest", and his own "natural selection", which, although possibly causing some perplexity, leads us to admit the following: Darwin (who did not sympathise with Spencer) aimed to highlight that his theory had as domains the sciences of Life and Man, from psychology to history according to what he had written in 1859 . He might also have aimed at opening some loophole in the Spencerian philosophical system or simply at broadening his audience. What is certain is that, since the end of the seventh decade of the 19th century, Darwin's theory circulated in local and global cultures almost always submissive to ideas of an illuminist nature (like the ideas of progress and perfectibility) and even dominated/forged by philosophical systems like H. Spencer's evolutionism or Ernst Hæckel's evolutionary monism.

Most interestingly, while presenting his work The descent of man (1871), Darwin distinguished and complimented Hæckel's work, among the various works on the animal ascendency of man, published after the $1^{\text {st }}$ edition of The origin of species, in 1859. References were made to the results that had been published by Wallace, Th. Huxley, Lyell, Vogt, Lubbock, Büchner, Rolle, etc., but these did not exceed the normal procedure among peers of a scientific community. Very different were the words Darwin 
dedicated to Hæckel's work and particularly to his Natürliche Schöpfungsgeschichte (1868), which suggests a communion of ideas between the English naturalist and the German naturalist-philosopher. Darwin gives the idea that his work The descent of man, and selection in relation to sex, brings nothing innovative in regards to the Hæckelian Natürliche Schöpfungsgeschichte. Even regarding the theme of sexual selection, Darwin states in The Descent of Man that, after 1859, only the German zoologist understood it. But, symptomatically, Darwin says nothing about the monist-evolutionary determinism of the universe, of the earth, and of life, elaborated by Hæckel, or particularly about the philosophical and political value of the mechanicist naturalization of man and his history that Hæckel defended in his Natürliche Schöpfungsgeschichte (1868).

On the other hand, although Darwin's work of 1871 directs the reader to Hæckel's genealogic trees, it shows itself cautious regarding the fundamental biogenetic law and all the remaining laws of the German naturalist's authorship, as, for example, the law of evolution (divergence and progress), the laws of heredity and adaptation, etc. This means that, even in the field of scientific inferences and deductions, Darwin's work The Descent of Man is not that close to Hæckel's Natürliche Schöpfungsgeschichte. What distances Darwin from Hæckel is not only the philosophical and political intent of the German naturalist, but also the invincible distance between Darwin's original theory and Hæckel's idiosyncratic version of the same theory, even though, apparently, Hæckel did not question natural selection as the main mechanism of organic evolution.

The doctrinal nucleus that gives unity to Darwin's work and upholds his reading of the history of the human species, explained in 1871, in his book The Descent of Man, is the theory of evolution by natural selection, meaning the "preservation of favoured races" or the "survival of the fittest", in the struggle for life.

This statement, apparently peaceful, is far from consensual among darwinologists. The specialist Yvette Conry, namely in "Le statut de La descendance de l'homme et la sélection sexuelle", in De Darwin au darwinisme: science et idéologie, Paris, 1983, considers that the anthropo-historical and social theory of Darwin, presented in The Descent of Man, departs from the biological theory of 1859 . In a few lines, the author argues that in The Origin of Species, Darwin operated a scientific revolution, whereas in 1871, the key concept of natural selection started to function as a law of progress, transfiguring the Darwinian evolution. Moreover, the latter covered itself with the ideological mantel of triumphant liberalism. According to Yvette Conry's perspective, the history of man is not presented in rigorously naturalistic moulds, since the book of 1871 conveys a set of ideological norms present in the works of Spencer, Bagehot, Galton and others, as, for example, the technological criteria to evaluate the degree of civilization, the colonising myths, the hierarchy of human races, the cultural universalism of an European matrix, the superiority of the European civilization, etc. For Yvette Conry, one of the best indicators of the non-scientific character of the book of 1871 is the lack of rigour in the distinction of the terms nation, race and population.

In our perspective it is undeniable that the book of 1871 bears profound marks of Darwin's socio-cultural background. However, Yvette Conry makes a radical distinction between science and ideology and believes that, departing from the scientific theory of 1859, Darwin could have elaborated, textually, "une bio-anthropologie de la différence, du pluralisme et de la contingence”, i. e., a scientific bio-anthropo-historical-social 
Darwinism. To accomplish this, the English naturalist only had to remain faithful to the principles of 1859. As, according to Yvette Conry, The Descent of Man is an ideological work and not an extension of the 1859 text, she logically concluded that social Darwinism does not exist. What Darwin elaborated was an ideological theory of society and history that the author draws close to Herbert Spencer's social evolutionism and the like, whether individualists or holists. It is undeniable that Darwin's 1871 book reflects ethnocentric and classicist stereotypes (for example, the bio-moral superiority of the bourgeois), but what we point out as most relevant is that, like in the 1859 work, natural selection continues to be the creating power of evolution - a power that, in 1871 , was reinforced by sexual selection.

Unlike Yvette Conry, the historian-epistemologist Patrick Tort advocates that Darwin always separated himself from the Darwinisms-Evolutionisms, whether Spencerian (reference-norm of individualist social Darwinism), or from the holists or racialists and the eugenicists. According to Patrick Tort's interpretation, the Darwinian theory is as much scientific in 1871 as it was in 1859 and has no relation with a series of isms that, since the end of the $19^{\text {th }}$ century, maid claims for such a relation: neo-liberalism, racism, eugenicism, social selectism, etc.. In order to support his stance, Patrick Tort two-folded the Darwinian revolution. Thus, following a first scientific revolution in 1859, which inaugurated a new logic of the historicity of all living beings, Darwin operated a second scientific revolution in 1871 with his work The descent of man, and selection in relation to sex. In very synthetic terms, Tort argues that, in the 1871 book, Darwin founded an anthropology, a morality and a socio-politics of solidarities: "une socio-politique des solidarités", absolutely distinct from Spencerian liberal evolutionism and all of the social and political doctrines based on competition in unequal conditions or in coercive selectionism.

The defence of the second Darwinian revolution is sustained by the so-called "reversive effect of evolution" ("L'effet réversif de l'évolution. Fondements de l'anthropologie darwinienne", in Darwinisme et société. Direction de Patrick Tort, Paris, Presses Universitaires de France, 1992). By this expression Patrick Tort means that, according to Darwin, in the course of human history, natural selection gives place to education and conflict is replaced by cooperation and the protection of the disfavoured, since these practices reveal themselves as advantages to the civilizational evolution of the human species. Thus, in human history, natural selection selects values and anti-selectionist social behaviours.

In our understanding, the Darwinian texts of 1859 and 1871 allow for a different interpretation of the summarized interpretations presented. In our perspective, natural selection is one and the same in 1859 and in 1871 . The theory of the biological evolution of all living beings (1859) extends itself in the bio-anthropo-socio-historical theory of 1871 that Darwin had announced since 1859 with these very expressive words: "light will be thrown on the origin of man and his history". And this idea is reinforced in the following editions: "Much light will be thrown on the origin of man and his history".

Indeed, in 1871, Darwin strived to demonstrate that man was descended from an inferior form, both physically and mentally, and that his genealogy is not punctuated by ruptures with sudden changes, but processed with slow, short and successive steps. "Natura non facit saltum", according to the cannon defended in 1859 "as natural selection acts solely by accumulating slight, successive, favourable variations, it can produce no great 
or sudden modification; it can act only by very short and slow steps". The Darwinian originality lies, mainly, in the evolutionary mechanism defended, thus, the hypothesis according to which man is the modified descendent of a long series of ancestors, or better, the co-descendent of some ancient organic form, inferior and extinct, although implicit in The Origin of Species, was publically assumed by various naturalists between 1859 and 1871, namely Carl Vogt, Th. Huxley, Ch. Lyell, Ludwig Büchner and Ernst Hæckel, respectively in 1862-63, 1863, 1863, 1866 and 1868. However, the Darwinian work The Descent of Man was decisive in substantiating this scientific hypothesis.

When ending the book of 1871, Darwin highlighted that man still preserves marks of his lower origin: "Man still bears in his bodily frame the indelible stamp of his lowly origin”. For example, some useless organs, like the rudimentary tail, but also in the psychological realm there is an abundance of evidence of man's ascendency from animal. In The Origin of Species, Darwin had already announced the complete naturalization of the mental, emotional and moral faculties of man: "Psychology will be based on a new foundation, that of the necessary acquirement of each mental power and capacity by gradation". A significant part of the book of 1871 deals precisely with the comparison of man's mental and moral faculties with those of the inferior animals and Darwin concludes that their nature is the same, although in man they have achieved a much higher level, what, in turn, was explained by the natural selection of useful variations, assisted by the action of sexual selection and the heredity effects of the use of the brain. The nerve cells of the brain of all vertebrates derive from the nerve cells of the common ancestor of the kingdom and, therefore, it is not surprising that, even the sense of the beautiful and the patterns of beauty of these animals "generally coincides with our own standard". In the book of 1872, The Expression of the Emotions, that completes The Descent of Man, Darwin argued in favour of the universality of body language of the various emotions, their gradual acquisition through the long series of ancestors of man and, therefore, their innate and instinctive character.

In summary: besides stating the common ascendance of man and of the other vertebrates, and the close physical and psychological kinship between superior mammals and human beings, Darwin remained faithful to the evolutionary mechanism presented in 1859. In fact, we agree with John Greene's perspective, namely his 1995 article entitled "La révolution darwinienne dans la science et la vision du monde": "sous tous ses aspects (physiques, mentaux, moraux, esthétiques, religieux), l'humanité devait être considérée comme le résultat de processus similaires — variation aléatoire, lutte pour l'existence, sélection naturelle secondée par la sélection sexuelle et les effets hérités de l'usage des facultés psychiques — à ceux qui avaient produit les autres êtres vivants". It was this light that illuminated the Darwinian understanding of the origin of man and his history. This means that the driving force of humanity's history is exactly that which enabled and determined all natural history, i. e., the mechanism of organic, mental and social evolution is one and the same: the natural selection of the fittest (races or individuals) in the struggle for existence.

The Darwinian version of historical and social Darwinism was synthesized by the English naturalist in the final paragraphs of his The Descent of Man, from where the following passage was drawn: "Man, like every other animal, has no doubt advanced to his present high condition through a struggle for existence consequent 
on his rapid multiplication; and if he is to advance still higher, it is to be feared that he must remain subject to a severe struggle. Otherwise he would sink into indolence, and the more gifted men would not be more successful in the battle of life than the less gifted (...) There should be open competition for all men”. What elevated man to the condition of a civilized social being was the struggle for existence, which should not be neutralised, because, without competition, natural selection cannot act in the sense of preserving the most capable, "the fittest". This means, in the area of social engineering, that the states should avoid all measures that hinder the functioning of the natural mechanism of evolution. However, the power of human laws is not absolute. For Darwin, no protectionist measure of the weak, was, is, or will be, efficient and lasting enough to replace the laws of nature. In 1872, in a letter sent to Heinrich Fick, professor of Law at the University of Zurich, the English naturalist clearly expressed his selectionist optimism: "I fear that Cooperative Societies, which many look at as the main hope for the future, likewise exclude competition. This seems to me a great evil for the future progress of mankind. - Nevertheless under any system, temperate and frugal workmen will have an advantage and leave more offspring than the drunken and reckless". In this letter, Darwin reaffirms his faith in natural selection and speaks against the economic organisations and the levelling social conducts of all individuals, "the good and bad, the strong and weak".

The economic and social policy which better harmonizes with the laws of nature does not seem to be, as Patrick Tort intends, "une socio-politique des solidarities". Regarding social engineering, we think that Darwin is very close to Spencerian liberalism. With "the advancement of the welfare of mankind" in mind, it was most important to guarantee the success of the best ("the most able"; "the fittest"), which would happen on its own, as long as the imprudent-inferior man ("recklessinferior") did not benefit from a public and private solidarity that would stimulate his multiplication and, therefore, increase his numeric superiority. Anyhow, Darwin does not fear that the larger number of disqualified may threaten the historic preservation of the elites. For this to be true, the access to the superior scientific, artistic, religious, moral, etc., cultures should not be solely the privilege of a few due to their economic and family tradition, but a conquest of those who are intellectually most gifted. This does not mean that Darwin supported the principle of equal conditions and opportunities for all individuals, for such equality was unsustainable in the light of his doctrinal nucleus: variation or inter-individual inequality, struggle and selection. In general, those who posses the most advantageous variations of a certain trait will end up victorious, because natural selection is the last judge, an unfaultable judge that rewards "the fittest".

In the end, what fuels Darwin's historic and social optimism is his faith in natural selection. It was not due to the grace of God or due to man's illusionary free will that some human races achieved high levels of civilization. In developing the topic "Natural selection as affecting Civilised Nations", Darwin argued that artificial selections practiced during the historic process (like the elimination of the best in war) did not supress the power of natural selection. It is, therefore, understandable that in the realm of social engineering, Darwin did not support any kind of eugenic fundamentalism, which does not mean that the English naturalist condemned positive eugenics, because he believed in its civilizational advantages. 
In summary: the Darwinian revolution in the sciences of Life and Man is one and the same revolution. Since the 1860 's, this scientific and cultural revolution has met as many variants as its students and interpreters, a reason that helps explain the longevity and projection of the Darwin Industry. And, this industry continues to prosper, through the ongoing of new studies about Darwinism and evolution, from country to country, and case to case, in the history of science and culture during the last 150 years. 